\title{
Josiah's Reform in Judah (2 Kgs 22-23//2 Chr 34- 35: Implications for Nigeria in Pursuit of a Sus- tained Democracy
}

\author{
SAMSON Olusina Olanisebe (DEPARTMENT OF RELigious STUdies, \\ OBAFEMI AWOLOWO UNIVERSITY, NIGERIA)
}

\begin{abstract}
Josiah was a young boy of eight years when he assumed the position of leadership over the Southern kingdom of Israel. Before his ascension to the throne, there were many structural defects in the kingdom. The immediate task before him was how to restructure and re-engineer the socio-religious decay he met on the ground, to which he responded promptly and with a record of success. This paper, therefore, through narrative analysis, identifies the leadership and followership qualities that assisted Josiah in his reform policy in Southern Israel and recommends, through content analysis, the imbibing of those qualities by the Nigerian leaders and citizenry in their quest for a sustained democracy.

KEYWORDS: Democracy; followers; Josiah’s reform; leadership role; Nigeria.
\end{abstract}

\section{A INTRODUCTION}

The concept of democracy is traceable to the ancient Greeks, specifically the city-state of Athens in the fifth century BCE. The word democracy is derived from two Greek words "demos" meaning the people and "kratos," meaning "power" or "rule." 1 Defining democracy is a herculean task because there is no universally acceptable definition. However, it has been defined by various scholars based on the features that a true democracy must have. Those features include a system where people rule themselves, a society based on equal opportunities and individual merit rather than hierarchy or privilege, a system of welfare and redistribution aimed at narrowing social inequalities, decision making based on majority rule, to mention just a few. ${ }^{2}$ In the words of Badru, democracy is a system of government that enables both the leaders and the citizens to be conscious

* Article submitted: 26/01/2017; peer-reviewed: 20/03/2017; accepted: 11/07/2017. Samson Olusina Olanisebe, "Josiah’s Reform in Judah (2 Kgs 22-23//2 Chr 34-35: Implications for Nigeria in Pursuit of a Sustained Democracy,” OTE 30 (3) 2017, 770784. DOI: https://doi.org/10.17159/2312-3621/2017/v30n3a13

1 Angelika Klein, Yusuf Kiranda, and Regina Bafaki, Concepts and Principles of Democratic Governance and Accountability (Kampala: Konrad-Adenauer-Stiftung, 2011), 2.

2 Klein, Kiranda and Bafaki, Concepts and Principles, 2-3. 
of what is required, and accomplish it for the betterment of that society in terms of political, social and economic development. ${ }^{3}$ The elementary definition of democracy by Abraham Lincoln is "the government of the people by the people and for the people." " From this definition, the key word that keeps reverberating is the people. This means democracy is all about the people. The leaders who are elected are first and foremost part of the people. They have been elected to act in trust on behalf of the people for the common good of the people. If democracy is therefore to be sustained and seen as functional, both the leaders and the led have roles to play and responsibilities to discharge in order to achieve the aim of democracy in Nigeria. It is in this light that this paper examines the story of a man named Josiah from the biblical point of view, his rulership in a monarchical system of government, beaming the searchlight largely on his leadership qualities that assisted him to be judged as a successful King in his administration, and also looks at the response of his followers, their responsibilities that made the King succeed. This is done with a view to understanding the nexus between the character of the leaders and the led for the success of the implementation of any governmental policy. A narrative-critical approach has been chosen for this study, while acknowledging the role of a historical-critical study of the texts and the author's or redactor's theology that has been interwoven with the texts, takes the story in the text at its face value as an accurate account of the event described in the texts and not fiction. Also in the narrative approach, the significance of a text is important as the author's and the reader's intentions do indeed play an important role in the interpretation of the texts, but the only author and reader that we have access to is the implied author and reader in the text. ${ }^{5}$

\section{B THE IDENTITY OF THE BOOK OF THE LAW FOUND IN THE TEMPLE DURING JOSIAH'S REFORM}

The historical-critical analyses of the books of kings and chronicles have been done by scholars. Rosenbawn has chronicled some of the scholars' views. For instance, Julius Wellhausen assumed that Kings was a product of two editions, one a pre-exilic and the basic statement of Deuteronomistic History (DH), and the second, a post-exilic retouching of the basic statement to bring it up to date. Cross, also supporting Wellhausen, adds that the first edition was written in the era of Josiah as a programmatic document of his reform and of his revival of the Davidic state and comprises the bulk of Deuteronomistic history. The second edition is exilic in $550 \mathrm{BCE}$ and consists of (a) an updating of the history after

3 Fatai A. Badru, "Patriarchy and Constraints of Democratic Political Space of Women in Nigeria,” UJP 2 (2005): 78.

4 Tolu Lawal and Ogunro V. Olukayode, “Democracy and Development in Nigeria,” IJDevSus 1/2 (2012): 450.

5 Ronél Meylahn, "Narrative-Critical Approach as Hermeneutical Framework for a Creative Dialogue between Biblical Sources and Secular Extra-Biblical Sources: The Lord of the Rings as an Entry into the Book of Revelation,” VetE 30/1 (2009): 193-194. 
Josiah, and (b) a retouching which confirms Judah's fall to Samaria and Manasseh's role to that of Jeroboam. ${ }^{6}$

Knoppers has appealed to the incomparability formular describing kings as good and excelling in gracious acts and making judgments based on the specific features of a monarch's reign, in which that king is deemed unique or incomparable and as such concludes that "there is none like him.” For instance, Solomon is lauded for unparalleled wisdom and wealth, Hezekiah for unparalleled trust and Josiah for unparalleled reforms. This formular has succeeded in revealing the redaction layer in the Books of Kings. However, this incomparability formular does not conflict with one another, but indicates unity rather than disunity in Deuteronomistic history. ${ }^{7}$

Commenting on 2 Kgs 22-23, Monroe is of the opinion that the chapters contain two major strata, the first being the pre-exilic stratum which stems from priestly circles in Jerusalem and which contains strong parallels to ideas and terms present in the holiness code, and the second being the post-exilic Deuteronomistic stratum which recasts the "h" source. ${ }^{8}$

On the Chronicler history, it must be noted that Chronicles is considered to be a summary for the entire scriptures. Kalimi has identified the fact that the book of chronicles has been underutilized and marginalized by the Jewish people probably as a result of the fact that most of the narratives in the books have parallels in other earlier biblical books (Samuel to Kings), and the parallel texts in Chronicles are considered unjustly as dull and worthless repetitions. ${ }^{9}$ Critical dates for the Chronicler range from 515 to 350 BCE. It is to be noted that no modern scholar proposes a date which would make the Chronicler a contemporary, much less a predecessor of the Deuteronomist. In other words, the Chronicler is considered to be much later than the Deuteronomist, and the Deuteronomistic work as we have was by no means the Chronicler's only source.

Until recently, the Chronicler has suffered the misfortune of being considered historically inaccurate source on the grounds that his work copied the Deuteronomistic materials. However, this position has since been challenged

6 Jonathan Rosenbaum, "Hezekiah’s Reform and the Deuteronomistic Tradition," HTR 72/1-2 (1979): 24-25.

7 Gary N. Knoppers, “'There was None like Him’: Incomparability in the Books of Kings.” CBQ 54/3 (1992): 412-414.

8 Anthony J. Frendo, review of Josiah's Reform and the Dynamics of Defilement: Israelite Rites of Violence and the Making of Biblical Text, by Lauren S. Monroe, HS 55 (2014): 453.

9 Isaac Kalimi, "History of Interpretation the Book of Chronicles in Jewish Tradition: From Daniel to Spinoza,” RB 105/1 (1998):7-8. 
with the work of some scholars who have demonstrated that the chronicler possessed historically accurate information outside the Deuteronomistic materials. Rosenbawn summarizes the views of Eissfeldt and Myers who argue that

... in addition to the Deuteronomistic history, the Chronicler was privy to historical sources such as copies of official documents, memoirs, official lists of various types which he may have completed from oral tradition and studies of his own. Moreover, he has access to temple archives and official court histories of Israel. ${ }^{10}$

Kalimi also adds that the chronicler, in his bid to make the sources used in his book clear to his audience, interprets some sources that need clarification by replacing uncommon words with common words, omitting unclear idioms and phrases in order to make them comprehensible to his audience, bringing other texts into harmony to ease the mind of his unlearned readers, and sometimes he explains what happened and why. ${ }^{11}$ Jonker depicts Chronicles as reforming history because he sees the books as an attempt to reformulate and sanitize the older tradition about the past, as well as an attempt to reformulate the identity of God's people in the changed socio-historical circumstances of the late Persian era. ${ }^{12}$

From the above, it could be established that Josiah's accounts both in the Deuteronomist and Chronicler are historically verifiable and accurate though written at different periods, for different purposes and in different contexts.

The accounts of Josiah's reform are documented in both 2 Kgs 22-23 and $2 \mathrm{Chr} 34-35$. It is to be noted that discrepancies have been identified in the account of the writers of the books of Kings and that of Chronicles probably owing to the use of different sources by the compilers of both books. One of the points of interest to scholars in the story of Josiah's reform is the identity of the book of the law that was found in the temple during the repair ordered by Josiah. Many biblical scholars such as De Wette (who first propagated the hypothesis that the origin of the book of Deuteronomy was to be connected with the book of the law found in the temple during Josiah's reform, ${ }^{13}$ and argued that the "discovered" scroll had been composed not long before its “discovery”), ${ }^{14}$ Albright ${ }^{15}$

10 Rosenbaum, “Hezekiah’s Reform,” 26-27.

11 Isaac Kalimi, "Placing the Chronicler in His Own Historical Context: A Closer Examination,” JNES 68/3 (2009):183-184.

12 Louis C. Jonker, "Reforming History: The Hermeneutical Significance of the Books of Chronicles,” VT 57/1 (2007): 25.

13 Leslie J. Hoppe, “The Death of Josiah and the Meaning of Deuteronomy.” LASBF 48 (1998): 32-33.

14 Nadav Na'aman, “The 'Discovered Book' and Legitimisation of Josiah's Reform,” JBL 130/1 (2011): 47.

15 William F. Albright, "A Brief History of Judah from the Days of Josiah to Alexander the Great,” BA 9/1 (1946): 2. 
and Mayes ${ }^{16}$ believed that the law book that was found by Josiah was the book of Deuteronomy. However, Robinson challenged this earlier position by proposing the Holiness Code of Lev 15-26 as the likely book found in the temple owing to the fact that all the injunctions of the keeping of the covenant, the Passover, the destructions of wizard and familiar spirits, the threat of judgment against disobedience upon which scholars have based their judgment to be the book of Deuteronomy are also found in the Holiness Code of Leviticus. ${ }^{17}$

Furthermore, scholars are sharply divided on the contents of the discovered law book. Henige has categorized scholars' arguments on the contextual plausibility of the story of the finding of the book of the law into five main groups which comprise (i) blind acceptance/paraphrases (yes, because this is what the Bible says); (ii) defended acceptance (yes, but with justification); (iii) unconcerned/oblivious (maybe, maybe not, but it doesn't really matter); (iv) dubious (could have been, but probably was not); and (v) reflexive rejection (no way). ${ }^{18}$

Some others also considered whether the finding of the book was the motivation for Josiah's reform or not. For instance, while the Deuteronomist believes that the consequence of the finding of the law book was the motivation for Josiah's reform, the Chronicler history believes that the reform was already ongoing before the law book was found. In addition, the Chronicler history supplies other vital information which was not mentioned by the Deuteronomy redactor of the books of Kings. For example, Chronicles makes clear that Shaphan was not the only person appointed by the King in the repair of the Temple; rather he did it along with Maaseiah, the governor of the city and Joah the recorder. Also, details of what purpose the timber was to be used for, names of the overseers and various types of personnel employed were supplied by the Chronicler history. ${ }^{19}$ Hoppe is of the opinion that the story of the discovery of the law book was a fiction created by a nomistic redactor of the Deuteronomistic History. To him, the narrative is another example of Judah's past being transformed into homiletic-type reflection based on the assumptions of Judah's relationship with Yahweh as envisioned in the book of Deuteronomy. Therefore, the whole of 2 Kgs 22-23 is a literary product designed to persuade people to Deuteronomy's point of view and to demonstrate that Deuteronomy's teachings were known in Josiah's time and were, in fact, Mosaic in origin. ${ }^{20}$

16 Andrew D. H. Mayes, “King and Covenant: A Study of 2 Kgs chs. 22-23,” Herm 125 (1978): 35.

17 Donald W. B. Robinson, “Josiah’s Reform and the Book of the Law,” (London: Tyndale, 1951), online: https://biblicalstudies.org.uk/pdf/tp/josiah_robinson.pdf.

18 David Henige, "Found But Not Lost: A Sceptical Note on the Document Discovered in the Temple Under Josiah,” JHebS 7/1 (2007): 5.

19 Robinson, “Josiah’s Reform,” https://biblicalstudies.org.uk/pdf/tp/josiah_robinson .pdf.

20 Hoppe. "Death of Josiah,” 37. 
To Mayes, the pre-Deuteronomist account of Josiah's reform that he stood under the judgment of God after his righteous acts is historically improbable; it is unlikely that such a reform would have been carried out simply on the basis of a book discovered in the course of the temple repairs. Rather, it is a theological story which has its main focus on the finding of the book of the law found in the temple and on pushing Josiah forward as a righteous King who acted according to the laws of Moses. However, he admits that the historicity of the reforms carried out by Josiah is not in doubt. ${ }^{21}$ To further establish the Deuteronomic history as the source of the Josiah's story, Nelson believes that Joshua, the successor of Moses, was an earlier figure of Josiah based on three main propositions. First, Joshua was commanded by Yahweh to keep the book of the law and meditate on it day and night and not to turn from it to the right or to the left (Josh 1:8). This book of the law was no longer mentioned until it was discovered by Josiah who was described as a king who did what was right in the sight of the Lord and walked in all the ways of his father David and turned not aside to the right hand or to the left (2 Kgs 22:2). Second, both engaged in covenant mediation between themselves and the people and made the people to pledge their unalloyed loyalty to God (Josh 8:30-35; 2 Kgs 23:1-3). Third, both kept the Passover in the place appointed by Yahweh (Josh 5:10-12; 2 Kgs 23:21-23). ${ }^{22}$

The discovered law book, though, may not be the motivating factor of Josiah's reform as suggested by the Chronicler history, it further accentuated the reform and assisted in getting the reform to a logical conclusion. To this extent, there is no way one can divorce the reform of Josiah from the book of the law that was found, whether at the beginning or in the middle of his reform. This is because after the discovery of the book of the law which was read to the hearing of the King, the reaction of Josiah (tearing his clothes, 2 Kgs 22:11; and bringing the people to enter into a covenant to do all that are written in the law book that was found, 2 Kgs 23:1-3) indicated that the reform he started was only a small "good" thing in comparison with what Yahweh required of them which their forebears had forsaken. That the law book that was found gave impetus to the reform of Josiah cannot be far-fetched in view of the fact that Josiah was young in age and had not seen many of those injunctions being practiced before his ascension to the throne; and the fact that the book of the law was not available to all to read in his private study to know what Yahweh had ordered them to be doing in his day unlike the present time where each believer may even have more than one version of the complete Bible.

Apart from the discovered book of the law, one area that has not been given consideration as regards the contents of the discovered book of the law was whether the prophecy about the birth and mission of Josiah was included.

21 Mayes, "King and Covenant," 44-45.

22 Richard D. Nelson, “Josiah in the Book of Joshua,” JBL 100/4 (1981): 534-536. 
Josiah was the only monarch in Judah whose birth and mission had been predicted ever before his birth by a young prophet during the reign of Jeroboam in $1 \mathrm{Kgs}$ 13:2. This issue is worthy of consideration because though a person is poised to do evil, at the awareness that he has been sent by God to do good, the knowledge may move him to want to fulfil the positive prophecy. However, this is not likely to be the case concerning Josiah because he had been described as taking positive steps even before the discovery of the law book. It may therefore be safely assumed that he had made up his mind right from the beginning of his reign to bring about positive transformation to the already decayed territory which he inherited from his father.

\section{THE SOCIO-POLITICAL AND RELIGIOUS REFORMS OF JOSIAH IN JUDAH}

Before the academic lens is focused on the life and times of Josiah, there is the need to highlight the situation of Judah before his assumption to the throne, because this will assist in situating his reform in proper perspective. Josiah began to reign in Southern kingdom of Israel around 639 BCE when he was eight years old. He inherited from his father a kingdom full of idolatry, immorality, bloodshed, violence and ignorance of God's will. His father Amon died during a battle with the Assyrians. The socio-economic condition was heavily characterized by prosperity and socio-economic disparity. Josiah's reform was therefore directed toward correcting social, political and religious ills of the day. ${ }^{23}$ Twelve years after the ascension of Josiah, Ashurbanipal, the Assyrian King, died. This provided a window of opportunity for Josiah to start his reform because there was political dislocation during the transition of power in Assyria. Josiah made use of the period of the interregnum to start planning for Judah's independence from the Assyrian hegemony. During this period, he made some administrative changes which positively affected the economy and which also gave birth to the revival of the national cult which the Deuteronomist emphasized. During his reign, also, he improved Judah's international relations, for Judah passed from the Assyrian to the Egyptian sphere of influence. ${ }^{24}$ This relation with Egypt gave Judah relative freedom in terms of internal political and religious affairs from the type of political domination that led Assyria to annex Aram, Israel and other territories in the region, since Egypt was only interested in commercial exploitation of Judah. ${ }^{25} \mathrm{He}$, together with the right people around him (Hilkiah the Priest, Prophetess Huldah and Prophets Jeremiah and Zephaniah), as recorded in the Chronicler history, embarked on an all-round reform leading to the exclusive worship of one God in one sanctuary; the centralized, national observance of the main festivals of the Jewish year; and a whole mass of legislation that covered

23 Iyede M. Ogheneochuko, “Josiah's Reform as a Model for Religious Political ReBranding in Nigeria,” AJBS 28/1 (2010): 107.

24 Hoppe, "Death of Josiah,” 39.

25 Hoppe, "Death of Josiah,” 39. 
social welfare and justice, community relationships and personal morality (2 Chr 34-35).

The account of the finding of the book of the law, the consternation of the king on hearing it read, and the zeal with which its injunctions were carried out formed one of the most thrilling episodes in Israel's history. ${ }^{26}$ Josiah's reform brought about two great effects on the people. The first was that it put a stop to all the different forms of sacrifices being made by the people in various sanctuaries since sacrifice was centralized to the Temple in Jerusalem. This also assisted the people of Judah in exile. The second effect was that the reform joined the Prophets to the Jerusalem ritual and priesthood, thus introduced the element of ceremony and ritual into prophetism. ${ }^{27}$

With the finding of the Deuteronomic code in 622 BCE, eighteen years into his reign, Josiah launched a full-scale politico-religious program for the reestablishment of the Davidic kingdom in Judah. ${ }^{28}$ It is on record that the three decades of Josiah's reign were characterized by peace, prosperity and reforms. They were among the happiest years experienced by Judah. ${ }^{29}$ Josiah started his reform by ordering the repair of the Temple. Shaphan the scribe was to collect from Hilkiah the high priest money to give to the workmen for their labor and for the procurement of building materials. The workmen were not brought into account because they were honest in their financial management (2 Kgs 22:7). In the process of the repair, a book was found by the workmen which was delivered to the priest Hilkiah who in turn delivered it to Shaphan and the latter read it in the hearing of the King (2 Kgs 22:3-11). Josiah was greatly disturbed upon hearing the contents of the book and discovering that they had disobeyed the injunctions of Yahweh and that danger was looming for him and the people as a result of the sins of their fathers. He sent delegates to Prophetess Huldah to inquire from God about the book, who in turn told them that the Lord was set to implement the punishment written therein. However, Josiah would be spared for his penitent heart and reaction upon hearing the contents of the book of the law (2 Kgs 22:12-20).

The King called an assembly of the people into the Temple and a covenant was made to the effect that they would all return to the ways of the Lord and do his biddings. In this act, the King was portrayed not only as one who stood in a special relationship with God but also as one of his people who functioned as Moses (Exod 24:3-8) and Joshua (Josh 24), in returning the whole people,

26 Edward T. Harper, "Historical Movements in Israel from the Reform of Josiah to the Completion of the Second Temple," BibW 11/6 (1898): 385.

27 Harper, "Historical Movements,” 386.

28 Frank M. Cross and David N. Freedman, “Josiah’s Revolt against Assyrians,” JNES 12/1 (1953): 56.

29 “Josiah's Heart for Truth,” Law of Liberty, www.lawofliberty.com/sermons /Resources/josiahsheartfortruth.pdf. 
including himself, to the laws of the covenant (2 Kgs 23:1-3). ${ }^{30} \mathrm{~A}$ list of actions taken by the King both in Judah and Samaria to the effect of the destruction of high places in the city and institution of right worship in the Temple was recorded in 2 Kgs 23:4-20. He also commanded Passover to be kept in accordance with what was written in the book of the covenant (2 Kgs 23:21-23). He made other reforms, he put away those with familiar spirits, wizard, seraphim, the idols and all abominations, so that he might conform to the laws (2 Kgs 23:24). ${ }^{31}$

One thing to also note from the Chronicler's History is that Josiah began the reformation from himself. He began to seek the Lord God of his father (2 Chr 34:3). Josiah was radical in the swiftness of his reform. He did not waste any more time after getting the road map of how the kingdom should be, rather he lunged into action. He was willing to pay the price of transformation. He went throughout all the length and breadth of Judah "removing," "tearing down," "burning," “demolishing," "slaughtering," “defiling," “doing away with,” "breaking," and "grinding to dust." All these are specific words indicating actions of a true reform(er).

\section{DEMOCRACY IN NIGERIA: THE JOURNEY SO FAR}

Nigeria's democratic governance since independence, and until 1999, was shortlived as a result of incessant military takeovers through coups d'état. After a period of sixteen years of military rule in Nigeria, the country returned to a democratic system of governance in 1999 which is currently running in the country. The nascent democracy is sixteen years old in Nigeria but with various challenges ranging from the qualities of the democratic leaders, impunity of corrupt public office holders, economic dislocation, free-for-show bickering among the law makers, insecurity, etc. Oni corroborates some of these challenges when he avers that sustained poor political leadership, defective constitutional arrangement, corruption, economic mismanagement, undemocratic internal party politics, fraudulent electoral system, rule of man instead of the rule of law, and lack of accountability and transparency as major impediment to democratic consolidation in Nigeria. ${ }^{32}$

For Arowolo and Aluko, the Nigerian democratic process had been bedevilled by electoral violence, manipulation of election results and restrained political participation which in turn produced poorly defined rules, inadequacy of political leadership and weak judicial administration. ${ }^{33}$ Gberevbie on his own

30 Mayes, "King and Covenant," 42.

31 Robinson, “Josiah’s Reform,” https://biblicalstudies.org.uk/pdf/tp/josiah_robinson .pdf.

32 Ebenezer O. Oni, "The Challenges of Democratic Consolidation in Nigeria, 19992007,” IJPGG 5/5.1 (2014): 1.

33 Dare E. Arowolo and Olukemi O. Aluko, "Democracy, Political Participation and Good Governance in Nigeria,” IJDevSus 1/3 (2012): 797-801. 
added weak democratic institutions as being a hindrance to sustainable democracy in Nigeria. ${ }^{34}$ Eke identified that political parties formed along tribal sentiments and intolerance and lack of accommodation among the political elites exemplified by the syndrome of winner-takes-all as factors responsible for inability to have political stability and true democracy in Nigeria. ${ }^{35}$ These challenges are threatening the nascent democracy in the country. The question is: What can be done to sustain democratic governance in Nigeria and what is to be sustained in democracy?

What is to be sustained in democracy is not the concept but the principles. There are certain principles that must be upheld in any democratic society. These principles include citizen participation, equality, political tolerance, accountability, transparency, regular, free and fair elections, economic freedom, control of the abuse of power, separation of power, bill of rights, a culture of accepting results of elections, human rights, multi-party system, neutrality of state institutions, and rule of law. ${ }^{36}$ Looking at the list of what democratic principles are, what mark can be awarded to Nigeria in view of how democracy is being practiced in the country? It can safely assumed that Nigeria is on the right course but there is still a long way to go to be able to realize democratic principles in the country and it is only then can we talk of democratic sustainability.

\section{E SUSTAINING DEMOCRACY IN NIGERIA: IMPLICATIONS FROM JOSIAH'S REFORM}

It must be stated at the outset that though Josiah reigned in a monarchical system of government and one may well think that there is no correlation between monarchy and democracy. This is true to an extent. However, when one examines the fact that it is not the system of government that really matters but the drivers and operators of the system, then one will appreciate the fact that good quality of a leader is germane to the working of any system of government. If a system of government has good principles, but the operators are bad people, those good principles will remain abstract. It takes a purposeful leader to translate good principles into practical reality in the real sense of governance. It is on this basis that lessons from Josiah who operated a monarchical system of government and succeeded would be suitable to follow by the Nigerian leaders and followers who are currently operating the democratic system of government.

For democratic principles to be sustained in Nigeria, both the leaders and the citizens have roles to play. All the key actors in political participation must be active and pro-active to their duties and responsibilities. They need to learn a

34 Daniel E. Gberevbie, "Democracy, Democratic Institutions and Good Governance in Nigeria,” EASSRR 30/1 (2014): 134.

35 Daniel Okwuchi Eke, Perspectives on a stable Democracy for Nigeria (Aba: Lord Onny International, 2001), 12-23.

36 Klein, Kiranda, and Bafaki, Concepts and Principles, 4-6. 
great many lessons from Josiah, a young King in Judah, who brought about positive changes in his domain. For instance, before his ascension to the throne, Judah was already on the way to exile through its evil deeds, but when Josiah came to power, he brought about changes and led the people back to the divine will. However, Judah's journey to exile started when Josiah's son and successor Jehoahaz did evil in the sight of the Lord. ${ }^{37}$ This indicates that the personality and programs of political leaders in power determine the direction in which the country will go, whether advancement or retrogression. Coupled with this is the fact that the successor to a good political leader also matters in the sustainability or otherwise of the good foundation that might have been laid by his predecessor.

The political leaders in Nigeria must know that the onus is on them to chart the course which the country must follow. According to Oyebode,

... those placed in leadership positions must be able to envision goals and aspirations for societies, communities and nation-states over which they exercise leadership roles. It is only after leaders have come up with policies, plans and programmes that the rest of the population would be able to key-in and synchronize their own projects and proposals with those enunciated by the leaders. ${ }^{38}$

They must build strong institutions that will make whoever occupies any position in the country align with the right principles that will sustain the reform. There should also be a continuation of government programs that will impact positively on the populace irrespective of the person or political party that is in control of the affairs of the country. This has been lacking in Nigeria and could not ensure democratic sustainability if allowed to continue. In addition, Josiah's predecessor had ignored the upkeep of the temple of Jehovah, and it was evidently a disaster area when he began to reign. However, he did follow go in the evil footsteps of his predecessor. He decided to distinguish himself and write his name in gold through the reforms he carried out.

In his reform, Josiah caused many religious officials who had desecrated the high places to be dismissed from their positions and forbade them from serving the altar of the Lord (2 Kgs 23:8-9). In like manner, those who were found to be corrupt in public office has to be removed from their posts and have their assets probed, and if found guilty of corruption, those assets had to be confiscated and added to the national assets to serve as a deterrent to others. The Buhari-led administration is taking a good step in this direction in his anti-corruption crusade. A case in point is the arrest and trial of the former national security adviser to the former president Goodluck Jonathan, Rtd. Col. Sambo Dasuki was alleged

37 Hoppe, Death of Josiah,” 36.

38 Akin Oyebode, "Nigeria's Leadership Deficit and Its Impact on National Development," in The Humanities and Leadership in Nigeria, ed. L. O. Salami, et al. (Ile-Ife: Faculty of Arts, 2014): 2. 
of diverting \$2.1 billion meant to purchase security ammunition to other private uses. The money was alleged to have been shared with politicians to run the 2015 general election, to which about 15 politicians had been linked. Some of the people with whom the money was shared had been returning the loot to the national coffers. ${ }^{39}$

In addition, Josiah commanded a "house-cleaning” and in the process someone found a copy of the book of the law. This copy of the book of the law that was found played a vital role to the success of his reform. For democratic principles to be well entrenched and sustained in Nigeria, the constitution of the country must be given its rightful place in the affairs of the country. The constitution is the law-book of any country and it has been put in place to regulate the conduct of all the people living in a geographically defined territory, both the political leaders and the citizenry. It is also a major safeguard of human rights, ${ }^{40}$ which is one of the principles of an ideal democracy. It is with this constitution that the political office-holders are sworn in, and they have to promise to promote and defend its principles and the territorial integrity of the nation. If only Nigerian political leaders were to be true to their promise and do things as demanded by the constitution, then the democratic principles and ideals would be sustained. It is then that the rule of law and equality of all citizens can be achieved. Good as this suggestion may be, Ilesanmi has shown that constitutional provisions in Nigeria are rather cosmetic rather than being real and fall short of providing the inter-cultural, inter-regional and pan-national confidence, but further accentuate the vulnerability of the destiny of the people and happiness of the individuals and communities. ${ }^{41}$ We are not oblivious of the fact that there are agitations from the different ethnic and regional entities in Nigeria of the need to reform or amend certain parts of the constitution, but if the latter should be respected and obeyed by all just as it is, it will go a long way in ensuring right behavior that can help grow and sustain democracy in Nigeria.

It is also clear that Josiah began the reform himself. This is a great lesson for democratic leaders in Nigeria. It is not enough to be giving directives to people, they need to lead by example. It is not enough to be campaigning against corruption, they must also be corruption-free in all their affairs. To this effect, the change mantra and national re-orientation program launched by the Buhariled administration with the caption "Change-Begins-With-Me", a positive step in the right direction if only the political class were to transform this mantra into

39 Hakeem Oladele, “15 Politicians Linked To \$2.1 Billion Arms Deal Scandal,” NAIJ, https://www.naija.ng/695476-dasukigate-15-top-politicians-linked-2-1-billionarms-deal-scandal-photos.html\#695476

40 Emmanuel O. Ojo, "Human Rights and Sustainable Democracy in Nigeria (19992003),” JSocS 13/1 (2006): 20.

41 Simeon O. Ilesanmi, "Constitutional Treatment of Religion and the Politics of Human Rights in Nigeria," AfAf 100/401 (2001): 534-535, doi: 10.1093/afraf 1100.401.529. 
reality first in their lives, they could be sure that Nigeria citizenry will also follow suit. All that followers in Nigeria need is honest and sincere leaders that will match their promises with actions and demonstrate that they are ready to follow.

On the part of the citizens, in Josiah's reform the people of his days, though they were neck-deep in corrupt religious and social practices, when they saw a leader who was ready to do good, they cooperated with him. Josiah started from himself by making a covenant to uphold the laws of God, when the people saw leadership by example, they had to follow suit. Nigerian political leaders should lead by example; when the followers see that they mean business, they will adjust to the laid-down standard. In addition, the repairs were not carried out in Southern Israel by expatriate contractors but the people who worked in various departments were drawn from among the Jews themselves. There was no record of giving of quotations for quality materials and eventually using inferior or substandard materials, no cases of corruption and abandonment of the project. Many of the major projects in Nigeria are being awarded to foreign contractors because many Nigerian contractors are either incompetent or fraudulent. When contracts are given to them, they either use sub-standard materials in order to gain more money or abandon the project when they see that there is a change in government though they have received almost all the money budgeted for the project. Nigerian contractors should have a change of attitude in this regard. They need to understand that this is their country and it is part of their responsibility to do whatever job given to them in such a way that the future generations will remember them for good.

Furthermore, for there to be a sustained democracy, there must be accountability on the part of the leaders and citizens. In the account of Josiah's reform all the key players in the repair of the temple were honest without being monitored. Though the society was already corrupted morally and religiously, there were still people who could be trusted with money. It was on record that the money contributed was handled by both the priest, the secretary to the King and different professionals in building construction and none was asked to give an account of their spending because they dealt faithfully (2 Kgs 22:7). How many Nigerian political leaders and leaders in other spheres of the country can come out clean if probe panels were to be set up to check their financial records while in office? Nigeria citizenry, especially the civil servants and contractors should emulate this honest and faithfulness qualities of the people of Judah in dispensing whatever responsibility and contract given to them.

\section{F CONCLUSION}

There is no doubt that a well-practiced democracy will bring about development. This is because the growth and development of democracy largely depend on the practice of its ethics, ideals and norm as they serve as bedrock for democratic consolidation and sustainability. These democratic principles, if strictly fol- 
lowed, will manifest in good governance, infrastructural development and consequently national development. ${ }^{42}$ For Nigeria to experience all-round national development, there is a need for the political leaders and the citizenry to stress and uphold the democratic principles of equalities, political participation, human rights, transparency, accountability, rule of law and due process, etc.: These are some of the principles seen during Josiah's monarchical reign in southern Israel that made him succeed in his reform agenda.

\section{BIBLIOGRAPHY}

Albright, William F. “A Brief History of Judah from the Days of Josiah to Alexander the Great.” BA 9/1 (1946): 1-16.

Arowolo, Dare E. and Olukemi O. Aluko. "Democracy, Political Participation and Good Governance in Nigeria.” IJDevSus 1/3 (2012): 797-809.

Badru, Fatai A. "Patriarchy and Constraints of Democratic Political Space of Women in Nigeria.” UJP 2 (2005): 77-101.

Cross, Frank M. and David N. Freedman. “Josiah’s Revolt against Assyrians.” JNES 12/1 (1953): 56-58.

Eke, Daniel Okwuchi. Perspectives on a Stable Democracy for Nigeria. Aba: Lord Onny International, 2001.

Frendo, Anthony J. Review of Josiah's Reform and the Dynamics of Defilement: Israelite Rites of Violence and the Making of Biblical Text, by Lauren S. Monroe. HS 55 (2014): 453-455.

Gberevbie, Daniel E. “Democracy, Democratic Institutions and Good Governance in Nigeria.” EASSRR 30/1 (2014): 133-152.

Harper, Edward T. "Historical Movements in Israel from the Reform of Josiah to the Completion of the Second Temple.” BibW 11/6 (1898): 382-396.

Henige, David. "Found But Not Lost: A sceptical Note on the Document Discovered in the Temple Under Josiah.” JHebS 7/1 (2007): 1-17.

Hoppe, Leslie J. "The Death of Josiah and the Meaning of Deuteronomy.” LASBF 48 (1998): 31-47.

Ilesanmi, Simeon O. "Constitutional Treatment of Religion and the Politics of Human Rights in Nigeria.” AfAf 100/401 (2001): 529-554. Doi: 10.1093/afraf/100.401 .529 .

Jonker, Louis C. "Reforming History: The Hermeneutical Significance of the Books of Chronicles.” VT 57/1 (2007): 21-44.

“Josiah's Heart for Truth.” Law of Liberty, www.lawofliberty.com/sermons/Resources /josiahsheartfortruth.pdf.

Kalimi, Isaac. "History of Interpretation the Book of Chronicles in Jewish Tradition: From Daniel to Spinoza.” RB 105/1 (1998): 5-41. . "Placing the Chronicler in His Own Historical Context: A Closer Examination.” JNES 68/3 (2009): 179-192.

Klein, Angelika, Yusuf Kiranda and Regina Bafaki. Concepts and Principles of Democratic Governance and Accountability. Kampala: Konrad-AdenauerStiftung, 2011.

42 Lawal and Olukayode, “Democracy,” 449. 
Knoppers, Gary N. “'There was None like Him’: Incomparability in the Books of Kings.” CBQ 54/3 (1992): 411-431.

Lawal, Tolu and Ogunro V. Olukayode. "Democracy and Development in Nigeria.” IJDevSus 1/2 (2012): 448-455.

Mayes, Andrew D. H. "King and Covenant: A Study of 2 Kgs Chs 22-23.” Herm 125 (1978): 34-47.

Meylahn, Ronél. "Narrative-Critical Approach as Hermeneutical Framework for a Creative Dialogue between Biblical Sources and Secular Extra-Biblical Sources: The Lord of the Rings as an Entry into the Book of Revelation.” VetE 30/1 (2009): 174-201.

Na'aman, Nadav. “The 'Discovered Book' and Legitimisation of Josiah's Reform.” JBL 130/1 (2011): 47-62.

Nelson, Richard D. “Josiah in the Book of Joshua.” JBL 100/4 (1981): 531-540.

Ojo, Emmanuel O. "Human Rights and Sustainable Democracy in Nigeria (19992003).” JSocS 13/1 (2006): 15-29.

Ogheneochuko, Iyede M. “Josiah’s Reform as a Model for Religious Political ReBranding in Nigeria.” AJBS 28/1 (2010): 102-114.

Oladele, Hakeem. “15 Politicians Linked To \$2.1 Billion Arms Deal Scandal.” NAIJ. Online: https://www.naij.com/695476-dasukigate-15-top-politicians-linked-2-1billion-arms-deal-scandal-photos.html.

Oni, Ebenezer O. "The Challenges of Democratic Consolidation in Nigeria, 19992007.” IJPGG 5/5.1 (2014): 1-29.

Oyebode, Akin. "Nigeria’s Leadership Deficit and Its Impact on National Development." Pages 1-6 in The Humanities and Leadership in Nigeria. Edited by L. O. Salami, L. O. Adewole, F. M. Ogunleye, D. O. Ogungbile, and A. O. Ogunyemi. Ile-Ife: Faculty of Arts, 2014.

Robinson, Donald W. B. “Josiah’s Reform and the Book of the Law.” London: Tyndale, 1951. Online: https://biblicalstudies.org.uk/pdf/tp/josiah_robinson.pdf. Rosenbaum, Jonathan, “Hezekiah’s Reform and the Deuteronomistic Tradition.” HTR 72/1-2 (1979): 23-43.

Dr. Samson Olusina Olanisebe, Department of Religious Studies, Obafemi Awolowo University, Ile-Ife, Nigeria. Email: soolanisebe@yahoo.com. 